\title{
PETER JARVIS (1937-2018)
}

\section{In memoriam}

Poslavljamo se od dragega prijatelja, podpornika in gostujočega profesorja na študiju andragogike na Univerzi v Ljubljani, dolgoletnega člana mednarodnega uredniškega odbora naše revije Andragoška spoznanja.

Svet ga pozna kot enega največjih mislecev, raziskovalcev na področju učenja in izobraževanja odraslih, osebnostnega razvoja in družbene vključenosti.

Dragi Peter, tvoje knjige so izhajale skoraj vsako leto. Slutil si prihodnost, razmišljal in globoko občutil svet. Svojo močno motivacijo za delo si črpal iz svoje naklonjenosti ljudem. Pokazal si, kaj globalizacija

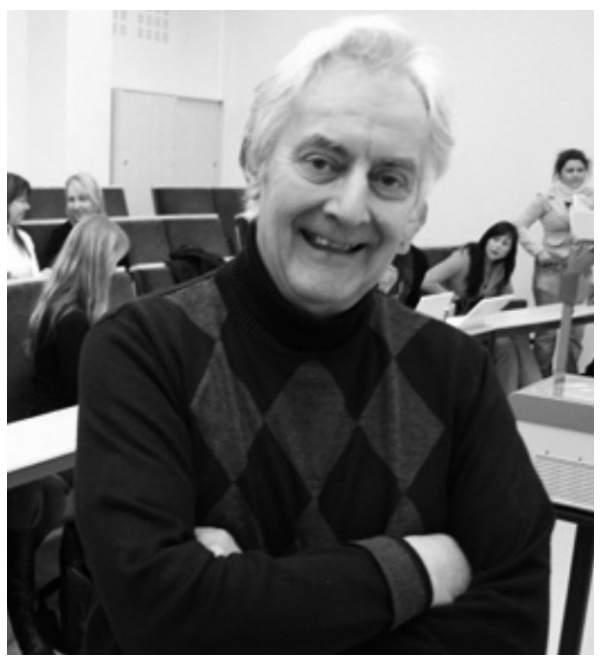
in razvoj prinašata dobrega, a hkrati si opozarjal na stranpoti. Tvoj optimizem je bil neizčrpen. Dragi so ti bili vsi ljudje. Enako pomembno ti je bilo odzvati se vabilu v Temišvar kot v New York, v majhen kraj na Filipinih kot v Toronto, v Ljubljano kot v Stockholm. Zate je bil pomemben vsak človek, v njem si videl velik kapital ustvarjanja, sposobnosti in čustev. Neumorno si deloval zato, da bi ta človek postal to, kar je, da bi v življenju imel priložnost izraziti se. Napovedoval si obrise nove, bolj humane družbe. Dokazoval si veliko poslanstvo nove tehnologije, podaljška človeških možganov. Ljudi razbremeni fizičnega in rutinskega dela, zdaj se lahko prepustijo lastni ustvarjalnosti, domišljiji, čustvom in brezmejni samoiniciativnosti.

Pred menoj je tvoja knjiga Paradoksi učenja, postajanje posameznika v družbi (prevod A. K., Paradoxes of Learning, On Becoming an Individual in Society), za teorijo vzgoje danes ena najpomembnejših. Okrog te osi so se vrtele naše pogoste diskusije in pisanja: razvita osebnost in človek kot družbeno bitje, posameznik in družba. Večna dilema teorije vzgoje in spet eno temeljnih vprašanj današnje vzgoje. Ker se spremembe dogajajo z veliko hitrostjo, ne čakajo generacij iz šol, na ta vprašanja bo morala najprej odgovoriti andragogika, da bo razvila generacijo odraslih. Vseživljenjsko izobraževanje in vseživljenjsko delovanje - o tem si pisal in govoril. 
Dragi Peter, tvoje ugotovitve so za današnji čas pomembne, ker odpirajo izobraževanju odraslih pot naprej, gledajo v prihodnost. Zato smo imeli občutek, da boš večno z nami. Vest, da si nas zapustil, nas je globoko prizadela. Ostal boš z nami s svojimi številnimi knjigami in skupnimi izkušnjami našega sodelovanja.

Ana Krajnc 